\title{
DAYA SAING KOMODITI KOPRA DI KABUPATEN MINAHASA SELATAN
}

\section{(Competitifness of commodities Kopra in The District of South Minahasa)}

\author{
Paulus A. Pangemanan \\ Yolanda P.I. Rori
}

\begin{abstract}
This study aims to determine the competitiveness of kopra in the South Minahasa based competitive advantage and comparative advantage. The benefits of this research are as reference material to South Minahasa regency government in formulating policies related to commodities kopra. Data used include primary data and secondary data. The primary data collection conducted by interviewing farmers, especially farmers kopra. While secondary data taken from the agencies involved in this study as the Central Bureau of Statistics, department of agriculture and plantations, and the service industry and trade. Determining the location of this research was done by using purposive sampling, where the number of samples is set at 10 samples in the village Pakuure 2 with the consideration that the village is a producer of kopra in the South Minahasa District of Tenga. The analysis used in this research that the Policy Analysis Matrix (PAM). The results showed that the coefficient of the ratio of the cost of domestic resource (DRCR) is smaller than one that is 0.660 which means it can compete to be the leading export commodities in the international trade market, while the value of the coefficient ratio of private costs (PCR) commodities kopra smaller than one that is 0,249 which means it can compete in terms of quality and price.
\end{abstract}

Keywords: Competitiveness, Comparative Advantage, Competitive Advantage, PAM

\section{ABSTRAK}

Tujuan penelitian ini adalah menganalisis daya saing (kompetitif dan komparatif) komoditi kopra di Minahasa Selatan. Penelitian ini dilakukan di Kabupaten Minahasa Selatan selama bulan April sampai Oktober 2016. Lokasi penelitian yaitu di Desa Pakuure 2 Kecamatan Tenga. Data yang digunakan meliputi data primer dan data sekunder.Pengumpulan data primer dilaksanakan dengan teknik wawancara pada petani khususnya petani kopra disentra produksi kopra Kabupaten Minahasa Selatan yaitu Kecamatan Tenga desa Pakuure2. Sedangkan data sekunder diambil dari instansi-instansi yang terkait seperti: Dinas Perindustrian dan Perdagangan Kabubaten Minahasa Selatan dan Provinsi Sulawesi Utara, Badan Pusat Statistik Kabupaten Minahasa Selatan dan Provinsi Sulawesi Utara dan Dinas Pertanian dan perkebunan Kabupaten Minahasa Selatan dan Provinsi Sulawesi Utara. Metode pengambilan sampel untuk data primer dalam penelitian ini dilakukan dengan teknik Purposive Random Sampling, dimana sampel yang ditetapkan dengan mempertimbangkan lokasi penghasil kopra di Minahasa Selatan, Kecamatan Tenga, Desa Pakuure2 dengan 10 sampel. Analisis data yang digunakan yaitu Policy Analysis Matrix (PAM) Berdasarkan hasil penelitian daya saing komoditi kopra di Minahasa Selatan memiliki keunggulan komparatif dan keunggulan kompetitif. Dikatakan komparatif karena komoditi kopra memiliki nilai koefisien rasio biaya sumberdaya domestik (DRCR) yang secara ekonomis lebih kecil dari satu yaitu 0,660 yang artinya bisa bersaing untuk menjadi produk unggulan ekspor di pasar perdagangan internasional, sedangkan dikatakan kompetitif karena nilai koefisien rasio biaya privat (PCR) komoditi kopra lebih kecil dari satu yaitu 0,249 yang artinya bisa bersaing dari segi kualitas dan harga.

Kata kunci: Daya Saing, Keunggulan Komparatif, Keunggulan Kompetitif, PAM 


\section{PENDAHULUAN}

Indonesia adalah Negara agraris yang perlu perhatian pemerintah pada sektor pertanian yang kuat dan tangguh, oleh karena itu salah satu sektor yang mendukung pertumbuhan ekonomi adalah sektor pertanian. Subsektor pertanian yang memegang peranan penting bagi perekonomian nasional adalah perkebunan.

Kelapa merupakan salah satu komoditas perkebunan yang memiliki nilai ekonomi penting bagi masyarakat tani di Indonesia. Indonesia memiliki luas areal kelapa sekitar 3,631,814 Ha dan memiliki produksi sebesar 3,031,310 ton yang artinya sebagian keluarga tani di Indonesia menggantungkan pendapatannya pada hasil kelapa (Direktorat Jenderal Perkebunan, 2014).

Salah satu sektor pertanian yang mendukung perekonomian Minahasa Selatan adalah komoditi kelapa. Kabupaten Minahasa Selatan merupakan salah satu kabupaten di Provinsi Sulawesi Utara yang merupakan sentra utama tanaman kelapa, dengan luas lahan kelapa seluas 47.810 ha yang merupakan lahan kelapa terluas kedua setelah Kabupaten Minahasa Utara yaitu 48.235 ha yang memproduksi kopra di Sulawesi Utara (BPS, Sulawesi Utara 2013).

Hamparan kebun kelapa yang luas menjadi pemandangan utama bagi Kecamatan Tenga Desa Pakuure yang dikenal sebagai Desa penghasil kopra di Minahasa Selatan. Untuk itu kegiatan pengembangan kelapa menjadi kopra di Minahasa Selatan merupakan kebutuhan dalam menunjang perekonomian dan kesejahteraan masyarakat dan mampu menghasilkan devisa bagi negara melalui pengembangan dan dukungan kebijakan pemerintah.

Analisis daya saing merupakan alat bantu untuk mengukur daya saing suatu komoditi. Komoditas dengan tingkat stabilitas daya saing yang tinggi memiliki potensi dan kemudahan dalam meningkatkan produktivitas untuk mencapai tingkat daya saing yang lebih baik.

\section{Perumusan Masalah}

Berdasarkan latar belakang yang telah dikemukakan, hal yang menjadi rumusan masalah dalam penelitian ini adalah bagaimana kepuasan masyarakat (konsumen) dalam mengkonsumsi minyak goreng curah di pasar Karombasan Manado.Berdasarkan latar belakang yang telah diuraikan diatas maka yang menjadi masalah dalam penelitian ini adalah apakahkomoditi kopra di Minahasa Selatan memiliki daya saing berdasarkan keunggulan kompetitif dan komparatif.

\section{Tujuan dan Manfaat Penelitian}

Sesuai dengan rumusan masalah di atas, maka yang menjadi tujuan dalam penelitian ini adalah untuk menganalisis daya saing (kompetitif dan komparatif) komoditi kopra di Minahasa Selatan. Sedangkan manfaat penelitian ini yaitu:

1) Sebagai bahan pertimbanan bagi pemerintah Kabupaten Minahasa Selatan dalam merumuskan kebijakan yang berkaitan dengan komoditi kopra.

2) Sebagai masukan dan kajian bagi penelitian selanjutnya.

\section{METODOLOGI PENELITIAN}

\section{Tempat dan waktu penelitian}

Penelitian ini dilakukan di Kabupaten Minahasa Selatan selama bulan April sampai Oktober 2016, mulai dari persiapan, pengumpulan data sampai pada pengolahan data. Lokasi penelitian yaitu di Desa Pakuure 2 Kecamatan Tenga.

\section{Metode Pengumpulan Data}

Data yang digunakan meliputi data primer dan data sekunder.Pengumpulan data primer dilaksanakan dengan teknik wawancara pada petani khususnya petani kopra disentra produksi kopra Kabupaten Minahasa Selatan yaitu Kecamatan Tenga desa Pakuure2. Sedangkan data sekunder diambil dari instansiinstansi yang terkait seperti: Dinas Perindustrian dan Perdagangan Kabubaten Minahasa Selatan dan Provinsi Sulawesi Utara, Badan Pusat Statistik Kabupaten Minahasa Selatan dan Provinsi Sulawesi Utara dan Dinas Pertanian dan perkebunan Kabupaten Minahasa Selatan dan Provinsi Sulawesi Utara 


\section{Metode Pengambilan Sampel}

Metode pengambilan sampel untuk data primer dalam penelitian ini dilakukan dengan teknik Purposive Random Sampling, dimana sampel yang ditetapkan dengan mempertimbangkan lokasi penghasil kopra di Minahasa Selatan, Kecamatan Tenga, Desa Pakuure2 dengan 10 sampel.

\section{Konsep Pengukuran Variabel}

Variabel-variabel yang digunakan dalam penelitian ini adalah:

$\square$ Karakteristik Petani

- Umur (Tahun)

- Tingkat Pendidikan (SD, SMP, SMA, Perguruan tinggi)

- Jumlah tanggungan

- Luas Lahan (ha)

Biaya Produksi (Harga Sosial) atau harga bayangan (Shadow Price) yaitu biaya yang dihitung untuk menggambarkan nilai sosial yang sesungguhnya bagi unsur-unsur biaya atau hasil, ntuk barang/komoditas yang diimpor dipakai harga CIF (Cost Insurance Freight), sedangkan untuk barang / komoditas yang di ekspor digunakan harga FOB (Free On Board).

Biaya produksi (Harga Privat) yaitu biaya yang dikeluarkan oleh petani terdiri atas :

Biaya input Tradable yaitu benih dan pupuk untuk tanaman (Rp)

- Biaya input Non-Tradable yaitu biaya tenaga kerja (Rp), sewa lahan (Rp) pengangkutan, penyusutan alat-alat pertanian.

Harga Kopra diperbatasan yaitu FOB $(\mathrm{Rp} / \mathrm{Kg})$

Harga jual kopra pada saat itu (private) yaitu $(\mathrm{Rp} / \mathrm{kg})$ ditingkat petani.

\section{Metode Analisis Data}

Analisis data yang digunakan yaitu Policy Analysis Matrix yang terdapat di Tabel 2.Baris pertama dari Matrik PAM adalah perhitungan dengan harga pasar (privat), yaitu harga yang betul-betul dibayarkan petani.Baris kedua merupakan penghitungan yang didasarkan pada harga sosial (shadow price), yaitu harga yang menggambarkan nilai sosial yang sesungguhnya bagi unsur biaya maupun hasil.(Pearson, 1989).

Policy Analisys Matrix (PAM)

\begin{tabular}{|c|c|c|c|c|}
\hline & \multirow[b]{2}{*}{ Penerimaan } & \multicolumn{2}{|c|}{ Biaya } & \multirow[b]{2}{*}{ Keuntungan } \\
\hline & & $\begin{array}{c}\text { Input } \\
\text { Tradable }\end{array}$ & $\begin{array}{c}\text { Input } \\
\text { NonTradable }\end{array}$ & \\
\hline $\begin{array}{l}\text { Harga } \\
\text { Privat }\end{array}$ & A & B & $\mathrm{C}$ & $\mathrm{D}$ \\
\hline $\begin{array}{l}\text { Harga } \\
\text { Sosial }\end{array}$ & E & $\mathrm{F}$ & $\mathrm{G}$ & $\mathrm{H}$ \\
\hline
\end{tabular}

Sumber :Pearson dkk, 2005

Keterangan :

A = Penerimaan Privat,

B = Biaya Input Tradable,

C = Biaya Input Non Tradable Privat

$\mathrm{D}=$ Keuntungan Privat

$\mathrm{E} \quad=$ PenerimaanSosial

$\mathrm{F} \quad=$ Biaya Input Tradable Social

G = Biaya Input Non Tradable Social

$\mathrm{H} \quad=$ Keuntungan Sosial

Kemudian dianalisis dengan indicator sebagai berikut :

1. Analisis keuntungan privat atau private profitability $(\mathrm{PP}): \mathrm{D}=\mathrm{A}-(\mathrm{B}+\mathrm{C})$.

Keterangan :

$\mathrm{D}=$ Profit atau keuntungan berdasarkan harga aktual (keuntungan privat)

$\mathrm{A}=$ Penerimaan (harga aktual). Penerimaan diperoleh dari hasil penelitian antara rata-rata jumlah produksi per hektar (kg/ha).

$\mathrm{B}=$ Biaya input yang diperdagangkan (Tradable) berdasarkan harga aktual.

$\mathrm{C}=$ Biaya faktor domestik Biaya output (Non tradable) berdasarkan harga aktual.

Jika keuntungan privat negative $(\mathrm{D}<0)$, maka petani mengalami kerugian atau tidak layak untuk diusahakan karena memiliki keuntungan diatas normal.

2. Analisis Keuntungan Sosial atau social profitability $(\mathrm{SP}): \mathrm{H}=\mathrm{E}-(\mathrm{F}+\mathrm{G})$ Keterangan : 
$\mathrm{H}=$ Profit atau keuntungan berdasarkan harga sosial

$\mathrm{E}=$ Penerimaan (harga sosial). Penerima diperoleh dari hasil perkalian antara ratarata jumlah produksi perhektar dikali dengan harga sosial kopra.

$\mathrm{F}=$ Biaya input yang diperdagangkan di pasar internasional

$\mathrm{G}=$ Biaya faktor domestik biaya input

(Non Tradable) berdasarkan harga sosial.

Apabila $\mathrm{H}<0$ maka komoditi kopra dikatakan tidak efisien.Sebaliknya jika $\mathrm{H}$

$>0$ menunjukkan bahwa usahatani kopra makin efisien dan memiliki keunggulan komparatif yang tinggi.

3. Efisiensi financial (Keunggulan kompetitif) dengan indikator Private cost Ratio: $\mathrm{PCR}=\mathrm{C} /(\mathrm{A}-\mathrm{B})$.

Usahatani dikatakan memiliki keunggulan kompetitif apabila nilai PCR < 1.Semakin kecil nilai PCR berarti semakin besar kompetitif.

4. Analisis efisiensi ekonomi atau keunggulan komparatif dengan indicator
Domestic Resource Cost Ratio : DRCR = G / (E-F). Nilai DRCR $<1$ menunjukkan usahatani kopra efisien atau menguntungkan secara ekonomis dalam pemanfaatan sumberdaya domestik dan apabila DRCR > 1 menunjukkan kegiatan tersebut tidak efisien.

\section{HASIL DAN PEMBAHASAN}

\section{Deskripsi Wilayah Penelitian}

Kabupaten Minahasa Selatan terbentuk berdasarkan Undang-Undang Nomor 10 Tahun 2003 tentang Pembentukan Kabupaten Minahasa Selatan dan Kota Tomohon di Provinsi Sulawesi Utara. Ibukota Kabupaten Minahasa Selatan adalah Kota Amurang yang berjarak $\pm 64 \mathrm{~km}$ dari Kota Manado. Secara geografis Kabupaten Minahasa Selatan terletak di antara $0^{0}, 47^{\prime}$ - $1^{0}, 24^{\prime}$ Lintang Utara dan $124^{0}, 18^{\prime}$ $124^{\circ} 45^{\prime}$ Bujur Timur.

Tabel 1. Luas Wilayah dan Penduduk Kabupaten Minahasa Selatan Menurut Kecamatan, Tahun 2014

\begin{tabular}{cccc}
\hline No & Kecamatan & $\begin{array}{c}\text { Luas } \\
(\mathrm{Km})\end{array}$ & Jumlah Pnduduk \\
\hline 1 & Modoinding & 46,98 & 11.676 \\
2 & TompasoBaru & 129,48 & 11.82 \\
3 & Maesaan & 143,98 & 9.81 \\
4 & Ranoyapo & 102,44 & 12.024 \\
5 & Motoling & 15,11 & 7.226 \\
6 & Kumelembuai & 37,89 & 6.595 \\
7 & Motoling Barat & 128,4 & 7.704 \\
8 & Motoling Timur & 50,4 & 8.903 \\
9 & Sinonsayang & 104,58 & 15.282 \\
10 & Tenga & 125,39 & 17.386 \\
11 & Amurang & 69,45 & 16.858 \\
12 & Amurang Barat & 103,4 & 15.222 \\
13 & Amurang Timur & 152,73 & 14.061 \\
14 & Tareran & 51,91 & 12.238 \\
15 & Tumpaan & 78,26 & 15.88 \\
16 & Suluun Tareran & 35,84 & 7.196 \\
\hline & Tatapaan & 108,19 & 9.023 \\
\hline & Jumlah & $1.484,47$ & 198.901 \\
\hline
\end{tabular}

Sumber: BPS Kabupaten Minahasa Selatan Tahun 2014 
Kabupaten Minahasa Selatan yang secara administratif memiliki batas-batas wilayah sebagai berikut:

Utara : berbatasan dengan Kab.

Minahasa

Timur: berbatasan dengan Kab.

Minahasa Tenggara

Selatan: berbatasan dengan Kab. Bolaang Mongondow

Barat : berbatasan dengan laut Sulawesi

Kecamatan Tenga adalah salah satu kecamatan yang berada di Kabupaten Minahasa Selatan yang terdiri dari 8 (delapan) desa yang salah satunya adalah Desa Pakuure2.Desa Pakuure2 merupakan tempat penelitian dimana sebagian besar dari penduduk tersebut bekerja dibidang pertanian khususnya petani kelapa yang diolah menjadi kopra.

\section{Karakteristik Responden}

\section{Umur Responden}

Umur mempengaruhi kemampuan seseorang untuk bekerja secara fisik dan cara berpikirnya. Berdasarkan hasil penelitian, umur berkaitan dengan pengalaman seorang petani.

Tabel.2. Umur Responden

\begin{tabular}{ccc}
\hline Umur (Tahun) & $\begin{array}{c}\text { Jumlah Responden } \\
\text { (orang) }\end{array}$ & Persentase (\%) \\
\hline $35-60$ & 4 & 40 \\
$61-71$ & 6 & 60 \\
\hline jumlah & 10 & 100 \\
\hline
\end{tabular}

Sumber : Diolah dari data primer

Golongan umur petani berada pada umur 3560 tahun yang berjumlah 4 orang dan golongan umur 61-71 tahun berjumlah 6 orang. Jadi sebagian besar dari responden berada pada umur 61-71, dimana umur tersebut sudah mempunyai pengalaman kerja dan dapat berpikir secara optimal terhadap hal-hal yang menyangkut pengambilan keputusan.

\section{Tingkat Pendidikan}

Berdasarkan hasil penelitian, pendidikan bukan merupakan salah satu faktor yang menentukan produktivitas petani yang ada di Desa Pakuure2, karena tinggi rendahnya pendidikan seorang petani tidak mempengaruhi petani dalam pengalaman bekerja.Sesuai dengan hasil penelitian, petani yang memiliki tingkat pendidikan yang rendah rata-rata memiliki keterampilan dan pengalaman kerja yang lebih dibandingkan dengan petani yang memiliki tingkat pendidikan yang lebih tinggi.

Diketahui bahwa 40 persen dari responden berada di tingkat pendidikan SD, 50 persen di tingkat pendidikan SMP, dan 10 persen berada di tingkat pendidikan SMA. Dilihat dari tabel di atas petani terbanyak memiliki tingkat pendidikan SMP.

Tabel 3.Tingkat Pendidikan Responden

\begin{tabular}{ccc}
\hline Tingkat Pendidikan & $\begin{array}{c}\text { Jumlah Responden } \\
\text { (orang) }\end{array}$ & Persentase (\%) \\
\hline SD & 4 & 40 \\
SMP & 5 & 50 \\
SMA/SMK & 1 & 10 \\
\hline
\end{tabular}

Sumber : Diolah dari data primer

Jumlah Tanggungan Dalam Keluaraga

Jumlah tanggungan keluarga adalah jumlah anggota keluarga yang harus dibiayai oleh kepala keluarga, di mana semakin tinggi jumlah tanggungan dalam keluarga maka semakin besar pengeluaran dalam keluarga.

Tabel 4 menunjukkan bahwa jumlah keluarga 6,5 , dan 1 orang memiliki persentase 10 persen, 3 orang memiliki persentase 40 persen dan 1 orang memiliki 
persentase 10 persen.

Tabel 4. Data Jumlah Tanggungan Dalam Keluarga Responden

\begin{tabular}{cccc}
\hline $\begin{array}{c}\text { Jumlah Tanggungan } \\
\text { Dalam Keluarga } \\
\text { (oranng) }\end{array}$ & $\begin{array}{c}\text { Jumlah Responden } \\
\text { (orang) }\end{array}$ & Persentase (\%) & $\begin{array}{c}\text { se } \\
\text { ken }\end{array}$ \\
\hline 6 & 1 & 10 & yan \\
5 & 1 & 10 & pr \\
3 & 4 & 40 & p \\
2 & 3 & 30 & m \\
1 & 1 & 10 & m \\
\hline Jumlah & 10 & 100 & \\
\hline
\end{tabular}

Sumber : Diolah dari data primer

\section{Luas Lahan}

Lahanyang dikelola oleh petani (responden) berbeda-beda luasannya. Berdasarkan Tabel 5, luas lahan yang dikelola oleh petani (responden) memiliki persentase yang sama dengan jumlah luas lahan yang berbeda, di mana responden yang memiliki luas lahan 0,5 - 3 ha dengan jumlah 5 orang begitu juga dengan petani yang memiliki luas lahan 4 - 5 ha dengan jumlah 5 orang.

\section{Tabel 5. Jumlah Petani dan Persentase \\ Luas Lahan}

\begin{tabular}{|c|c|c|c|c|c|c|c|c|}
\hline \multirow{5}{*}{$\begin{array}{c}\text { Luas } \\
\text { Lahan } \\
\text { (Ha) }\end{array}$} & \multirow{4}{*}{$\begin{array}{l}\text { Jumlah } \\
\text { Petani } \\
\text { (orang) }\end{array}$} & \multirow{4}{*}{$\begin{array}{c}\text { Persentase } \\
(\%)\end{array}$} & \multirow{4}{*}{$\begin{array}{l}\text { Luas } \\
\text { Lahan } \\
\text { (ha) }\end{array}$} & \multirow{3}{*}{$\begin{array}{c}\text { Rata-rata } \\
\text { Luas } \\
\text { Lahan }\end{array}$} & \multirow{3}{*}{ No } & & \multirow{3}{*}{$\begin{array}{c}\text { Jumlah Tenaga } \\
\text { Kerja (HOK) }\end{array}$} & \multirow{3}{*}{ Persentase $(\%)$} \\
\hline & & & & & & Jenis Kegiatan & & \\
\hline & & & & & & & & \\
\hline & & & & Petani & 1 & Pemeliharaan & 1 & 20 \\
\hline & & & & (Ha) & 2 & Panen & 2 & 40 \\
\hline $0,5-3$ & 5 & 50 & 8,5 & 1,7 & 3 & Pasca Panen & 2 & 40 \\
\hline $4-5$ & 5 & 50 & 22 & 4,4 & & Jumlah & 5 & 100 \\
\hline Jumlah & 10 & 100 & 30,5 & 6,1 & & & a primer & \\
\hline
\end{tabular}

Sumber : diolah dari data primer

\section{Penggunaan Sarana Produksi}

Sarana produksi berperan penting di dalam suatu usaha untuk mencapai produksi sesuai yang
diinginkan.Berdasarkan hasil penelitian tanaman kelapa khususnya yang diolah petani menjadi kopra diambil dari kelapa yang sudah produktif dimana benih kelapa adalah benih yang dipilih petani dari usaha sendiri.Petani di Desa Pakuure2 tidak menggunakan pupuk dalam pemeliharaan kelapa.

Pengangkutan merupakan sarana yang digunakan untuk mengangkut hasil produksi dari kebun. Di Desa Pakuure 2 pengangkutan menggunakan roda sapi milik sendiri dan ada petani yang menggunakan sistem sewa.

\section{Penggunaan Tenaga Kerja}

Tenaga kerja merupakan faktor penting dalam menentukan suatu aktivitas. Dalam mengelola usaha pertanian, petani mudah mendapatkan tenaga kerja karena sebagian besar penduduk di Desa Pakuure adalah petani. Penggunaan tenaga kerja pada petani kopra meliputi pemetikan, pengumpulan, pengangkutan, pembelahan kelapa, mengeluarkan daging buah kelapa dari tempurung, pengasapan sampai pada pengeringan dan dilakukan dengan sisitem borongan. Rata-rata tenaga kerja yang dalam borongan terdiri dari 2 orang.

Tabel 6. Rata-rata Penggunaan Tenaga Kerja Pada Kegiatan Pengolahan Kopra

Sumber : Diolah dari data primer

Penggunaan tenaga kerja pada pemeliharaan hanya menggunakan satu (1) orang tenaga kerja dengan persentase $20 \%$ sedangkan pada saat panen dan pasca panen menggunakan rata-rata dua (2) orang tenaga kerja dengan persentase $40 \%$. Penggunaan tenaga kerja dihitung menggunakan $\mathrm{HOK}$ 
(hari orang kerja), dengan menggunakan tenaga kerja dalam rumah tangga dan di luar rumah tangga.

\section{Biaya Tenaga Kerja}

Biaya tenaga kerja menurut kegiatan usahatani kopra di Desa Pakuure2 yang dilakukan dengan sistem borongan, tenaga kerja dibayar dari hasil penjualan kopra, yang bisa dilihat pada Tabel 7 .

Tabel 7. Biaya Tenaga Kerja Menurut Kegiatan

\begin{tabular}{ccc}
\hline No & Jenis Kegiatan & Aktual (Rp) \\
\hline 1 & Pemeliharaan & 100.000 \\
2 & Panen & 281.000 \\
3 & Pasca Panen & 281.000 \\
\hline & Jumlah & 662.000 \\
\hline
\end{tabular}

Sumber: diolah dari data primer

Biaya tenaga kerja menurut
kegiatan usahatani pemeliharaan sebesar Rp. 100.000 dan pada pada kegiatan panen dan pasca panen sebesar Rp.662.000 Biaya panen dan pasca panen lebih tinggi karena dilakukan dengan tenaga kerja sebanyak 2 orang.

\section{Penyusutan Alat}

Nilai penyusutan alat kopra menggunakan metode Annual Capital Recorvery Cost (pemulihan modal biaya), dengan metode ini biaya opurtunitas penyusutan ikut diperhitungkan karena sesuai dengan tingkat bunga.Perhitungan biaya penyusutan alat secara privat dan sosial.

Tabel 8. Nilai Penyusutan Alat Secara Privat dan Sosial

\begin{tabular}{ccccccc}
\hline $\mathrm{N}$ & Uraia & $\begin{array}{c}\text { Alat } \\
\text { Pengup } \\
\mathrm{as}\end{array}$ & $\begin{array}{c}\text { Lewan } \\
\mathrm{g}\end{array}$ & $\begin{array}{c}\text { Pisau } \\
(\mathrm{Rp})\end{array}$ & $\begin{array}{c}\text { Banguna } \\
\mathrm{n} \\
(\mathrm{Rp})\end{array}$ & $\begin{array}{c}\text { Sekop } \\
(\mathrm{Rp})\end{array}$ \\
& $\mathrm{n}$ & & & & \\
\hline \multirow{2}{*}{1} & Privat & 49.611, & 19.364, & 19.364, & 876.247, & 11.618, \\
& 4 & 5 & 5 & 7 & 7 \\
2 & Sosia & 45.195, & 18.078, & 18.078, & 818.035, & 10.846, \\
& 1 & 3 & 1 & 1 & 4 & 8 \\
\hline
\end{tabular}

Sumber : Diolah dari data primer
Nilai penyusutan alat yang di hitung dengan metode Annual Capital Recorvery Cost, di peroleh nilai penyusutan alat secara privat sebesar Rp. 976.206,8 dan nilai penyusutan alat secara sosial sebesar Rp.910.233,7

\section{Produksi, Harga dan Penerimaan}

Berdasarkan hasil penelitian yang diperoleh Produksi kopra di Desa Pakuure2 menggunakan kelapa Dalam, di mana petani tidak menggunakan bibit kelapa dari luar daerah. Di mana hasil penelitian diperoleh rata-rata produksi kopra per hektar untuk satu kali panen sebanyak $737,7 \mathrm{Kg}$, dengan harga jual kopra di tingkat petani adalah Rp.7000/kg, sehingga penerimaan rata-rata per hektar adalah Rp. 5.147.540

\section{Harga Sosial}

Pearson (2005) mengemukakan bahwa harga sosial adalah harga yang menggambarkan harga yang sesunggunya baik harga input maupun harga output. Harga sosial juga merupakan harga yang akan menghasilkan alokasi sumberdaya terbaik sehingga dapat memberikan pendapatan nasional tertinggi.

\section{a. Harga Free On Board (FOB) dan Cost Insurance and Freight (CIF)}

FOB dan CIF merupakan istilah perdagangan yang berkaitan dengan pengiriman barang yang menyangkut hak dan kewajiban pembelidan penjual barang, dan hanya berlaku untuk transportasi air. Harga FOB adalah biaya barang sampai diatas kapal, meliputi biaya pengangkutan kedermaga dan biaya pemuatan diatas kapal.Harga barang CIF merupakan harga yang dibebankan penjual kepada pembeli, termasuk biaya transportasi dan asuransi untuk barang yang dikirim, sampai barang tiba di pelabuhan negara pembeli (Bank Indonesia, 2014). Harga sodial dalam penelitian ini yaitu Rp. 14.671,62

\section{b. Harga Sosial Lahan}


Berdasarkan hasil penelitian, penentuan harga sosial didasarkan pada berapa nilai lahan tersebut apabila digunakan untuk komoditas lainnya yang juga menguntungkan. pada daerah penelitian sewah lahan untuk komoditas lainnya tidak ada karena sebagian besar berpenghasilan kopra dengan lahan milik sendiri. Nilai sosial lahan jika ditanami komoditi lain di daerah penelitian yaitu Rp.1.500.000/ha/Tahun.

\section{c. Harga sosial tenaga kerja}

Menurut Suryono (1980), dalam persaingan sempurna tingkat upah pasar akan mencerminkan nilai produktivitas marjinalnya. Pada keadaan ini besarnya upah dapat dipakai sebagai harga bayangan dari tenaga kerja.Tetapi pasar tenaga kerja di Indonesia, terutama tenaga kerja tak terdidik, tidak demikian keadaannya. Oleh karena itu tenaga kerja disektor pertanian kebanyakan merupakan tenaga kerja tidak terampil maka produktivitasnya akan lebih rendah sehingga harga sosial tenaga kerja lebih kecil (80\%). Jadi harga sosial tenaga kerja ditempat penelitian diasumsikan 80 persen dari harga privat. Harga sosial tenaga kerjanya sebesar Rp. 529.600

Keuntungan Privat dan Keuntungan Sosial Keuntungan privat dan keuntungan sosial terjadi karena penilaian dari unsur penerimaan biaya.Keuntungan privat dihitung berdasarkan harga aktual yang diterima oleh petani, sedangkan keuntungan sosial diperoleh jika terjadi pasar persaingan sempurna, dimana tidak ada kegagalan pasar (market failure) dan kebijakan pemerintah.

Tabel 9. Keuntungan Privat dan Keuntungan Sosial

\begin{tabular}{|c|c|c|c|c|}
\hline & \multicolumn{3}{|c|}{ Biaya (Rp) } & \multirow[b]{2}{*}{$\begin{array}{c}\text { Keuntungan } \\
\text { (Rp) }\end{array}$} \\
\hline & $\begin{array}{c}\text { Penerimaan } \\
\text { (Rp) }\end{array}$ & $\begin{array}{c}\text { Input } \\
\text { Tradable }\end{array}$ & $\begin{array}{c}\text { Input } \\
\text { NonTradable }\end{array}$ & \\
\hline $\begin{array}{l}\text { Harga } \\
\text { Privat }\end{array}$ & 4.013 .796 & - & 2.650 .103 & 1.363 .693 \\
\hline
\end{tabular}

\begin{tabular}{lllll} 
& 9.863 .090 & - & 9.863 .090 & 7.402 .327 \\
Sosial & & & & \\
\hline
\end{tabular}

harga privat komoditi kopra memiliki keuntungan sebesar Rp. 1.363.693 yang didapat dari hasil penerimaan dikurangi dengan hasil input nontradable, dengan penerimaan sebesar Rp. 4.013.796 yang bisa dlihat pada lampiran 8, dan biaya input nontradale sebesar Rp. 2.650.103 yang dihitung menggunakan annual capital recovery cost (private) ditambah dengan biaya sewa lahan dab biaya tenaga kerja. Sedangkan harga Sosial komoditi kopra memiliki keuntungan sebesar $\mathrm{Rp}$ 7.402.327, yang didapat dari hasil penerimaan Rp. 9.863.090 dikurangi dengan hasil input non tradable sebesar Rp. 9.863.090.

\section{Efisiensi finansial dan Efisiensi Ekonomi Efisiensi finansial dalam} penelitian ini diukur dengan menggunakan rasio biaya privat (Private cost Ratio, PCR) dengan efisiensi ekonomi dalam penelitian ini menggunakan biaya sumberdaya domestik (DRCR).

Tabel 10. Rasio Biaya Privat dan Rasio Biaya Sumberdaya Domestik

\begin{tabular}{ccc}
\hline No & Indikator & Nilai \\
\hline 1 & Rasio Biaya Privat (PCR) & 0,660 \\
2 & Rasio Biaya Sumberdaya Domestik & 0,249 \\
& $(\mathrm{DRCR})$ & \\
& &
\end{tabular}

\section{Sumber : Diolah dari data primer}

Komoditi Kopra dikatakan efisien karena rasio biaya privat (PCR) lebih kecil dari satu yaitu 0,660. Sedangkan nilai koefisien rasio biaya sumberdaya domestik (DRCR) lebih kecil juga dari satu yaitu 0,249.Dengan demikian komoditi kopra di Kabupaten Minahasa Selatan mempunyai daya saing berdasarkan keunggulan kompetitif dan keunggulan komparatif. 


\section{KESIMPULAN DAN SARAN}

\section{Kesimpulan}

Berdasarkan hasil penelitian daya saing komoditi kopra di Minahasa Selatan memiliki keunggulalan komparatif dan keunggulan kompetitif. Dikatakan komparatif karena komoditi kopra memiliki nilai koefisien rasio biaya sumberdaya domestik (DRCR) yang secara ekonomis lebih kecil dari satu yaitu 0,660 yang artinya bisa bersaing untuk menjadi produk unggulan ekspor di pasar perdagangan internasional, sedangkan dikatakan kompetitif karena nilai koefisien rasio biaya privat (PCR) komoditi kopra lebih kecil dari satu yaitu 0,249 yang artinya bisa bersaing dari segi kualitas dan harga.

\section{Saran}

Komoditi kopra di Minahasa selatan memiliki daya saing berdasarkan keunggulan komparatif dan keunggulan kompetitif yang artinya memberikan keuntungan. Hal ini dapat menjadi bahan pertimbanangan bagi Pemerintah di Kabupaten Minahasa Selatan dalam merumuskan kebijakan yang berkaitan dengan komoditi.

\section{DAFTAR PUSTAKA.}

Anonymous, 2008. Definisi Harga. http://organisasi.org/definisi-pengertianharga -tujuan-metode-pendekatanpenetapan-harga-manajemenpemasaran. Diakses tanggal 9 September 2016.

Badan Pusat Statistik2013. Kabupaten Minahasa Selatan DalamAngka. BPS Kabupaten Minahasa Selatan .

Badan Pusat Statuistik 2013. Sulawesi Utara DalamAngka.BPS Provinsi Sulawesi Utara.

Dinas Perkebunan (2013). Outlook Komoditas Pertanian-Perkebunan Minahasa Selatan.Pusat Data dan Informasi Pertanian.
Direktorat Jenderal Perkebunan. 2014. Luas Areal, Produksi dan Produktivitas Perkebunan di Indonesia. Pusat Data dan Informasi Pertanian

Daryanto A. 2009, Konsep Daya Saing. BPEE-Yogyakarta

Daryanto, A. 2004. Disparitas Pembangunan dan pentingnya keterkaitan perkotaanperdesaan di Indonesia, Sinergi DesaKota 1: 10-15

Gerungan, L. 2013. Analisis KeunggulanKomparatif dan Kompetitif Biji Pala diMinahasa Utara. Skripsi Sarjana Jurusan Sosial Ekonomi Pertanian Universitas Sam Ratulangi. Manado

Hamdy, 2001, Ekonomi Internasional, Ghalia Indonesia, Jakarta

Kementerian Pertanian. 2006. Prospek Usaha Tani Kelapa Menggembirakan. Jakarta: Badan Penelitian dan Pengembangan Pertanian Kementerian Pertanian.

Kementerian Pertanian. 2013. Pembenihan Tanaman Kelapa. Jakarta: Direktorat Jenderal Perkebunan Kementerian Pertanian.

Kementerian Pertanian. 2012.

Peningakatan Produksi, Produktivitas dan Mutu Tanaman Tahunan.

Pedoman teknis Tanaman Kelapa. Jakarta

Kementerian Pertanian. 2013. Statistik Perkebunan Indonesia 2012-2014 (Kelapa). Jakarta: Direktorat Jenderal Perkebunan Kementerian Pertanian.

Kohari, K., Ma'sum, M. dan Windiastuti, D. (2005). Dampak Kebijakan dan Pemasaran Terhadap Daya Saing Usahatani Kentang

di Kecamatan Kejajar Kabupaten Wonosobo.

Koylal, Johny dan Jemseng Abineno (2008).Keuntungan Relatif Produk Usahatani Kelapa Tua di Kecamatan Amarasi.Buletin Partner Tahun 15 No 1.Edisi Januari.Politeknik Pertanian Negeri Kupang.

Komet, M. 2000. Perencanaan 
Terpadu Pembangunan Ekonomi Daerah Otonom,Badan Pusat Statistik. Jakarta

Monke, E.A. dan Pearson, S.R. (1989).The Policy Analysis Matrix for Agricultural Development.Cornell UniversityPress, Ithaca.

Pearson, S., Carl Gotsch, dan Sjaiful Bahri.(2005). Aplikasi Policy Analysis Matrix pada Pertanian Indonesia.Terjemahan. Yayasan Obor Indonesia, Jakarta.

Porter, M.E. 1990. The Competitive Advantage of Nations. The Free Press. New York

Pearson, S.R. 2002. Outreach University Program Agricultural Policy Workshop. Faculty Of Agriculture, Sam Ratulangi University Collaboration With

BAPPENAS/YSAI/ DAI-FPSA AND
STANFORD UNIVERSITY. Lecture

Handout, Manado.

Riswandha lmawan. 2002. Peningkatan Daya Saing: Pendekatan ParadigmatikPolitis. Jakarta

Saptana, S. 2004. Efisien dan Daya Saing Usahatani Tebu dan Tembakau dalam Efisiensi dan Daya Saing Sistem Usahatani Beberapa Komoditas Pertanian di Lahan Sawah. Pusat Penelitian dan Pengembangan Sosial Ekonomi Pertanian.Badan Penelitian dan Pengembangan Pertanian. Bogor.

Sarmidi, 2009.Aneka Peluang Bisnis dari Kelapa.Lily Publisher.Yogyakarta.

Salvatore, D. 1997. Ekonomi Internasional. Edisi 1. Erlangga. Jakarta.

Sobri, 2011. Ekonomi Internasional. (Teori, Masalah dan Kebijaksanaannya). BPEE-Yogyakarta. Yogyakarta 